MIECZYSEAW WIELICZKO (Lublin)

\title{
„GRANICA" NIEMIECKO-RADZIECKA POMIĘDZY BUGIEM I NIEMNEM W LAT ACH 1939-1941
}

Ujęcie w tytule pojęcia granica w cudzysłów oraz dalsze stosowanie takiej formy zapisu, wynika nie tylko $z$ przenośnego znaczenia tego pojęcia sytuowanego pomiędzy geograficznymi realiami, jakie określają nazwy obydwu rzek, ale $z$ rzeczowego kontekstu tego problemu badawczego, w którym zmienność znaczenia występuje w takim stopniu (w czasie historycznym i przestrzeni geograficznej), że zostaje regulowana umową międzypaństwową - umową dotyczącą tylko zapisu tego pojęcia - i to, obok innych okoliczności, o których poniżej będą wzmianki, skłania do określenia prolegomenów dalszego wywodu. Są one ważne i z innego względu - złożoności podjętej problematyki, że używając dużego skrótu myślowego wymienię trzy grupy jej przesłanek, a to:

- międzynarodowe, związane $z$ faktem, że owa „granica" pomiędzy Niemnem a Bugiem stanowiła fragment transkontynentalnej linii podziału tej części kontynentu europejskiego pomiędzy, ogólnie określając, morzami: Bałtyckim i Czarnym. Z owej to linii określającej strefy interesów III Rzeszy Niemieckiej i Związku Radzieckiego, na poszczególnych jej odcinkach przyjmując równoleżnikowe podziały lokalne, wynikały implikacje narodowo-państwowe, i to określa następną grupę przesłanek,

- narodowe, których „wymiar" polski obejmu je przede wszystkim zasadniczy podział terytorium Rzeczypospolitej pomiędzy wspomniane państwa, podział będący następstwem ich wrześniowej agresji. Postaci inkorporacji (pojęcie occupatio bellica zdaje się trwać niezmiernie krótko, o ile w ogóle występuje...), będące następstwem debellatio jako uzgodnionej, jak to dziś wiemy, bezspornie agresji, te postaci w okolicznościach ustalanej „granicy” powodują wytworzenie kolejnej grupy przesłanek, 
- regionalne, wynikające $z$ takiej, a nie innej delimitacji i demarkacji „granicy” oraz przyszłego „pogranicza”, okoliczności całkowicie nowej $\mathrm{w}$ procesie historycznym na tym obszarze.

Zwrócić trzeba uwagę, że treść pojęcia „pogranicze" odbiega w omawianym przypadku od jego powszechnego rozumienia, pojmowanego jako tereny historycznie ukształtowanego współżycia i współistnienia różnych grup etniczno-językowych, narodowości i społeczności narodowych. $\mathrm{Na}$ ogół „pogranicze" jest terenem dyfuzji kultur, które są wytworem tych zbiorowisk (wspólnot) ludzkich, terenem intercesji na wielu płszczyznach stosunków międzyludzkich (w tym międzypaństwowych), oraz nierzadko obszarem zbliżenia odmiennego interioru narodowego. „Pogranicze” powstałe pomiędzy Bugiem a Niemnem w wyniku porozumień niemiecko-radzieckich z 23 sierpnia i 28 września 1939 r. ma charakter stykowy - bez współdziałania (choć nie jest to jednoznaczne...), przenikania, nawet bez kontaktu konfliktowego. Jest to „pogranicze" odmienne w swoim znaczeniu. Tej kwestii, przynajmniej w kilku wybranych fragmentach problematyki, zamierzam poświęcić uwagę, eksponując dwie ostatnie grupy przesłanek.

Powstał bowiem pośrodku ziem polskich obszar (pas) rozerwania wspólnoty narodowej, powstał nagle, likwidu jąc wszelkie formy interakcji ludzkiej społeczności lokalnych, które istniały, działały i rozwijały się jako spójne struktury. Społeczności lokalne, albo trochę szerzej - zbiorowości terytorialne, podlegały wpływowi zjawisk i procesów wynikających ze stosunku zasiedlenia terytorium - czyli więzi zamieszkania w danej okolicy (regionie) i jednostce organizacyjno-administracyjnej (wieś, przysiółek, kolonia, obszar dworski, miasteczko, miasto, przedmieście, dzielnica), więzi zamieszkania, w której usytuowane są role społeczne jednostek, grup i klas społecznych, także role społeczne narodowości współzamieszkałych (osiadłych, współistniejących) w ramach zbiorowości terytorialnej. Całość ta dzięki wielofunkcyjności ról społecznych jest zintegrowana, tworząca zbiorowość determinowaną warunkami wewnętrznymi i zewnętrznymi - obiektywnymi i subiektywnymi (przewaga tych ostatnich jest w warunkach wewnętrznych), całość współistniejącą na danym obszarze.

Jakakolwiek zmiana tej historycznie uksztaltowanej równowagi, w której nie brak także konfliktowych „interesów” o rozmaitym charakterze (religijno-kulturowym, gospodarczym, antagonizmów interpersonalnych etc.), ale nie przybierających trwałych tendencji walki, wygnanie, zniszczenie przeciwnika, bądź pozbawienie go warunków egzystencji przez wyzucie z dóbr - zmiana tej równowagi rozpoczęła się już w wyniku następstw społecznych agresywnej wojny. Zniszczenie jednak, i to bezpowrotne, systemu więzi 
społeczno-terytorialnej ludzkich zbiorowości dokonane zostało przy końcu zdarzeń wojny wrześniowej, kiedy wytyczono wpierw „linię demarkacyjną”, a zarazem „granicę” pomiędzy Bugiem a Niemnem. Zerwanie przez to więzi międzyludzkich w środowiskach lokalnych i zbiorowościach terytorialnych oznaczało osłabienie tożsamości ideowej, kulturowej, narodowej i jednostki, i zbiorowości. A to prowadzi do zniewolenia i wyniszczenia, do załamania postawy identyfikacyjnej jednostki. Nie ma już swobodnego wyboru wartości i celów, tego wszystkiego co stanowiło o najwyższej formie zbiorowej akceptacji. Zapanowała przemoc, przymusowa akceptacja narzuconej sytuacji, w której nie ma granic dla presji, ucisku, terroru i różnych form przemocy.

"Granica" pomiędzy Bugiem a Niemnem poprowadzona została przez ludne obszary środkowej Polski, gdzie w procesie dziejowym wytworzyły się wspólnoty terytorialne i współzamieszkałych z Polakami skupisk ludności żydowskiej w miastach i miasteczkach (rzadziej w środowisku wsi), a także ludności białoruskiej (w pewnej liczbie statystycznych „tutejszych”), głównie w południowej części woj. białostockiego, poczynając od powiatów nadbużańskich. Inne mniejszości narodowe, Litwini jeszcze w największym skupieniu, Rosjanie i Ukraińcy, zamieszkiwali na interesującym nas obszarze zaledwie sporadycznie, nie tworząc zwartych skupisk osadniczych o większym znaczeniu.

Wszystko co powyżej posłużyło do charakterystyki socjo-historycznej problematyki wybranego odcinka „granicy", co tworzyło historię społeczną tego terytorium, kształtowało się i funkcjonowało przez stulecia - nagle, wraz z koncepcją wyznaczenia stref interesów III Rzeszy Niemieckiej i ZSRR, uległo degradacji o tak eksterminacyjnym charakterze, że poznanie możliwie szczegółowe przyczyny sprawczej, jej terminus a quo, i wszystkich okoliczności od delimitacji i demarkacji poczynając - poznanie uwarunkowań tej obcej kategorii w procesie historycznym wydaje się celowe i ważne.

Podjęty problem „granicy" niemiecko-radzieckiej, wytyczonej po wspomnianych układach, jest tyleż znany, co wymagający dalszych badań. Oto ujawnione dotąd przekazy źródłowe, głównie niemieckie, albo pochodzące $z$ niemieckich kręgów dyplomatycznych, zaś ostatnio, jakże liczne także źródła proweniencji radzieckiej - nie pozwalają odpowiedzieć na tak proste pytanie, w której to fazie rozmów niemiecko-radzieckich pojawiła się koncepcja „linii demarkacyjnej”, i do tego złączonej z biegiem rzek: Pisa-Narew-Wisła-San ${ }^{1}$. Można, jak dotąd, domniemywać o intencjach obydwu stron, że

1 Problem stosunków niemiecko-radzieckich w przededniu II wojny ma wyraźnie dwa aspekty: zawieranych i natychmiast ogłaszanych układów datowanych 23 sierpnia 
zmierzały do nadania powziętym decyzjom cech najwyższej trwałości, jeżeli tę "granicę", inaczej stref interesów, starano się umocnić granicą naturalną ( "mokrą") wzdłuż nurtu rzek. Dodać do tego trzeba jeszcze drugie spostrzeżenie, że czyniono to w największym pośpiechu, kiedy opuszczono w pewnym momencie nazwę "Pisa” i tutejszy odcinek "granicy”. Do szczegółów zaraz przyjdzie powrócić. Wpierw jeszcze sprawa dalszych źródeł będących podstawą tego studium². Sa to bowiem materiały unikatowe, i jak na wa-

i 28 września oraz dołączonych do nich tzw. tajnych protokołów dotyczących wstępnej delimitacji stref interesów w Europie Środkowo-Wschodniej oraz innych uzgodnień i aspektów wzajemnych stosunków, protokołów, których istnienia wypierała się strona radziecka do 1992 r., gdy w wersji niemieckiej teksty były znane od procesu norymberskiego i wielokrotnie zostały na Zachodzie ogłoszone. U nas jedna $\mathrm{z}$ pierwszych oficjalnych jego publikacji przygotował R. Nazarewicz, Międzynarodowe tło agresji Rzeszy Niemieckiej na Polskę w 1939 roku. Wstęp i wybór dokumetów..., Warszawa 1986, s. 155, poz. 50, ale opatrzył tekst notą: „Autentyczność tego dokumentu nie została potwierdzona przez stronę radziecka". Dodam, że strona radziecka powołała się na pkt 3 pierwszego protokołu w nocie dyplomatycznej przedstawionej w nocy 26 czerwca 1940 r. Nicolae Dianu, posłowi rumuńskiemu w Moskwie, żądając „zwrotu” Besarabii i „przekazania” Bukowiny. Jest to jedyny znany fakt w tym zakresie. Dlatego warto odnotować cały wręcz proces ujawniania prawdy o układach niemiecko-radzieckich i ich następstwach terytorialnych, czego obrazem jest historiografia. W. Bielewicz, Radziecko-niemiecki pakt o nieagresji z 23 VIII 1939 roku w publikacjach historyków radzieckich (1987-1989), [w:] Polski wrzesień 1939, pod red. W. W. Bednarskiego i J. Mańdziuka, Lublin 1991, s. 45-75. A. Korzon, Wybrane tematy $z$ historiografii sowieckiej i rosyjskiej o 17 września 1939 r. i jego konsekwencjach, [w:] 17 września 1939. Materiały $z$ ogólnopolskiej konferencji historyków, Kraków, 25-26 października 1993, pod red. H. Batowskiego, Kraków 1994, s. $61-74$ (jest to w pewnym stopniu kontynuacja poprzedniego opracowania), oraz J. Buszko, 17 września w opiniach polskiej historiografii emigracyjnej, tamże, s. 91-102.

2 Archiwum Akt Nowych w Warszawie, zespół: Regierungs des Generalgouvernament. Hauptabteilung Finanzen, 964 (dalej, Reg. Fin.). Przy piśmie, VI a 756/40/6665 z 2 października 1940 r. i VI a 801/40/6665 z 18 października 1940 r. Ministerstwo Spraw Wewnętrznych Rzeszy przysłało do urzędu Generalnego Gubernatora w Krakowie 114 kart protokołów (wraz z załącznikami) dotyczących niemiecko-sowieckich układów granicznych. Jest to zbiór dokumentów dotyczących odcinka stref interesów przebiegającego przez ziemie Rzeczypospolitej. Druga grupę dokumentów, ale o charakterze uzupełniajacym, stanowią niemieckie akta proweniencji wojskowej z zespołów: T-77 Oberkommando der Wehrmacht (OKW), T-78 Oberkommando des Heeres (OKH) i T-311 Akten Deutscher Stabskommandos, Armmegruppen oraz T-312 Akten Deutscher Stabskommandos, Armeen. Jest to fragment kolekcji tzw. mikrofilmów aleksandry jskich National Archives of USA przechowywanej w kilku polskich archiwach centralnych. Wymienione sa w zbiorze Dokumenty i Materiały Wojskowego Instytutu Historycznego. Część z tych dokumentów została dołączona do ostatnio podjętej edycji źródeł radzieckich, Agresja sowiecka na Polskę w świetle dokumentów. 17 września 1939, t. I, Geneza i skutki agresji, Warszawa 1994, t. III; Działania Wojsk Frontu Białoruskiego, Warszawa 1995, wybór i opracowanie C. Grzelak, S. Jaczyńshii, E. Kozłowski. Jest to jak dotąd najbardziej kompletny zbiór dokumentów dyplomatycznych dotyczących stosunków niemiecko-radzieckich związanych z Polską, od listopada 1938 r. Pod względem edytorskim źródeł historycznych jest to zbiór wydany wzorowo (por. instruktywny wstęp, s. 5-28), i skracając przypisy, powołuję tylko te dokumenty. 
runki badań kompletne, pozwalające na wypowiedź w pełni udokumentowaną ${ }^{3}$.

Próba interpretacji faktu wyznaczenia „granicy” w ogólnie południkowym kierunku od terytorium Niemiec (Prus Wschodnich) ku centrum państwa, skłania do zwrócenia uwagi na szerszy zakres stosunków międzynarodowych, w których zbliżenie niemiecko-radzieckie po kilkunastu latach bezwzględnej walki politycznej - uchwały antyfaszystowskie Kominternu oraz pakt antykominternowski, wojna domowa w Hiszpanii $\mathrm{z}$ jej międzynarodowymi kontekstami - stanowiło okoliczność tyleż nieoczekiwaną co do postaci traktatowych oraz zaskakującą w szybkości realizacji i likwidacji terytorialnej postaci państwa polskiego, wraz z pozostałymi sąsiadami Rzeczypospolitej. Zarówno, uży jmy skrótu pojęciowego, historyczna tradycja antypolskiego współdziałania rosyjsko-niemieckiego (pruskiego) od doby wojny północnej i utrwalenia się rosyjskiej ingerencji w wewnętrzne sprawy Polski, jak też konsekwentna polityka przeciwpolska okresu między wojnami, stanowiły przesłanki zbliżenia ${ }^{4}$. Pamiętać jednak należy, że zarówno interesująca nas „granica” pomiędzy Bugiem a Niemnem, jak też cała „linia demarkacyjna" dzieląca ziemie Rzeczypospolitej, aż po źródła Sanu, były fragmentem generalnej zmiany stosunków politycznych w tej czesści kontynentu i rozszerzeniem przede wszystkim wpływów ZSRR z konsekwencja tzw. wojny zimowej z Finlandią na przełomie 1939/1940 r., zagrabienia z obszaru Rumunii Besarabii i Bukowiny w czerwcu 1940 r. i likwidacji suwerenności państw bałtyckich w lipcu-sierpniu 1940 r. ${ }^{5}$ Układy niemiecko-ra-

3 Dziesięć załączników z danymi topograficznymi „granicy” stanowi jedyny w swoim rodzaju zbiór, który znalazł się w aktach „rządu” GG dość przypadkowo; dobiegała kresu dyskusja prawno-polityczna w Rzeszy na temat charakteru (statusu) Generalnego Gubernatorstwa, co zbiegło się z zawarciem porozumienia co do nazwy „granicy" niemiecko-radzieckiej. Władze GG zostały więc obligowane do poniesienia kosztów ustawienia słupów granicznych, wobec tego zażądano od rządu Rzeszy „uzasadnienia”, które przysłano z Berlina w postaci tejdokumetacji - świadectwa porozumień niemiecko-radzieckich uznawanych przez ponad pół wieku za tajne...

4 L. Grosfeld, Polskie aspekty stosunków niemiecko-sowieckich $w$ okresie międzywojennym, NOW „Krytyka” (poza debitem), Warszawa 1989, s. 43. H. Batowski, Antecedencje 17 września 1939, [w:] 17 września 1939, op. cit, s. 17-32. E. Duraczyński, Polska $w$ polityce Moskwy latem 1939, tamże, s. 33-52. A. Czubiński, Miejsce Polski w hitlerowskich planach ekspansji i podbojów, tamże, s. 135-152. Warto zestawić te opinie z tekstem wystapienia z 31 sierpnia 1939 r. W. M. Mołotowa na IV sesji Rady Najwyższej ZSRR w sprawie ratyfikacji niemiecko-sowieckiego paktu o nieagresji, [w:] Agresja sowiecka, t. I, op. cit., dok. nr 47, s. 97-102. Tekstu układu nawet nie odczytano w sali obrad i został ratyfikowany...

5 M. Wieliczko, Układy międzynarodowe $w$ Europie środkowo-wschodniej (sierpień-listopad 1939), [w:] Polski wrzesień, op. cit., s. 19-44, tenże, Polityczne położenie ziem mię- 
dzieckie z 23 sierpnia i 28 września przedzielone zbrojną agresją na Polskę 1 i 17 września 1939 r. są więc faktami o szczególnie doniosłym znaczeniu międzynarodowym, w którym współodpowiedzialność ZSRR za wybuch II wojny światowej, ostatnio zyskująca coraz większą uwagę historiografii $^{6}$, wydatnie podważa radzieckie pojmowanie „misji wyzwoleńczej Armii Czerwonej" na terytorium Rzeczypospolitej, „neutralności” w latach 1939-1941, a nawet pojęcia „Wielkiej Wojny Ojczyźnianej”, nie wzbudzających dotychczas wątpliwości w oficjalnej historiografii ${ }^{7}$. Tamtejszy spór naukowy tyleż dotyczy przeszłości, co „pożywia” aktualne tendencje i motywacje polityczno-propagandowe, ale to już inna sprawa. Powróćmy do okoliczności ustalenia „granicy” niemiecko-radzieckiej pomiędzy Bugiem a Niemnem.

Daje się tu zauważyć dwie fazy w przebiegu tego faktu, a to:

- porozumienia w ramach "tajnego protokołu" z jego zmianami przed radziecką agresją 17 września 1939 r.,

- korekta północnego odcinka „granicy” od Pisy do Niemna (rzeki Czarnej Hańczy) i ustalenie „ostatecznej” delimitacji w wyniku „terytorialno-

dzy środkowym biegiem Dniestru, Prutu i Seretu w latach 1914-1947, [w:] Polacy w Motdawii, pod red. ks. E. Walewandra, Lublin 1995, s. 90-116, szczególnie s. 103-112 i przyp. 10-21. J. Korzeń, Dramat narodów battyckich, Wyd. „Pokolenia” (poza debitem), Warszawa 1987, szczególnie s. 32-44. P. Łossowski, Agresja 17 września 1939 r. a paŕstwa battyckie, [w:] 17 września..., op. cit., s. 151-164. J. Gurba, Granica państwowa ZSRR, [w:] W pięćdziesiata rocznicę ZSRR, Lublin 1972, s. 17-20, mapy V-VII. Podsumowuje wyniki agresji: 1 września terytorium ZSRR obejmowało obszar $21540000 \mathrm{~km}^{2}$, a po zakończeniu VII sesji Rady Najwyższej ZSRR 7 sierpnia 1940 r. obszar wzrósł do 22107200 km², w tym pow. wysp $267390 \mathrm{~km}^{2}$ oraz wód przyległych $226280 \mathrm{~km}^{2}$.

6 M. Zgórniak, Europa w przedeniu wojny. Sytuacja militarna w latach 1938-1939, Kraków 1993, szczególnie rozdz. IX, s. 269-186, rozdz. XI, s. 300-325, rozdz. XII, s. 366-406 oraz rozdz. XVI, s. 484-526. Tenże, Wspótpraca wojskowa Niemiec i ZSRR przed agresja 17 września 1939 r. i dziatania Armii Czerwonej na terytorium II Rzeczypospolitej, [w:] 17 września 1939, op. cit., s. 119-134. S. Sierpowski, Ewolucja sytuacji międzynarodowej u schyłku okresu międzywojennego, tamże, s. 103-118. M. Nurek, Dyplomacja brytyjska wobec militarnej i politycznej agresji ZSRR (wrzesień-październik 1939), tamże, s. 165-182. B. A. Starkow, Sojusz czy konfrontacja. Kwestia polska w historii stosunków radziecko-niemieckich $w$ latach 1933-1937, [w:] Problem granic i obszaru odrodzonego państwa polskiego (1918-1990), pod red. A. Czubińskiego, Poznań 1992, s. 155-172. M. K. Kamiński, Geneza rozpętania przez Niemcy i Zwiazek Sowiecki drugiej wojny światowej, [w:] „Wiadomości Historyczne" 1994, s. 1-14. Ważna bibliografia załącznikowa: dokumenty, opracowania, wspomnienia i pamiętniki.

7 Wydanie długo oczekiwanych źródeł: Dokumienty wniszniej politiki SSSR 1939, t. XXII, cz. 1-2, Moskwa 1992 oraz pojawienie się w historiografii „problemów” związanych $\mathrm{z}$ interpretacja układów radziecko-niemieckich, por. przyp. 1, wywołało po $1989 \mathrm{r}$. dyskusję na łamach pism naukowych: „Woprosy istorii”, „Nowaja i nowiejszaja istorija” oraz "Wojenno-Istoriczeskij Żurnał”, dotyczącą daty rozpoczęcia II wojny (sic!), jej charakteru, udziału ZSRR etc., zaś podglebiem tego wszystkiego był proces rozpadu ZSRR i „odłączanie się" coraz to nowych b. republik, od bałtyckich poczynając. 
-politycznych przekształceń" także obejmujących Litwę w następstwie tej agresji.

Jak nadmieniłem, nie do ustalenia jest szczegół poprowadzenia rozgraniczenia sfer interesów z biegiem rzek, bowiem nawet szyfrant i sekretarz ambasadora Rzeszy Schulenburg, pomimo dużej wierności pamiętnikarskiej dla faktów, tę kwestię pominął ${ }^{8}$. Pozostaje to więc nie do końca wyjaśnione, choć pkt 2 tajnego protokołu dodatkowego do układu o nieagresji jest w tym względzie jednoznaczny ${ }^{9}:$, W wypadku terytorialno-politycznych przekształceń na obszarach należących do państwa polskiego podział sfer interesów między Niemcami a ZSRR przebiegać będzie mniej więcej wzdłuż linii rzek Pisa, Narew, Wisła i San".

Pominąc tu trzeba implikacje historyczne powodujące taką „intencję" rozbioru Rzeczypospolitej, a zauważyć wypada, że wpierw Niemcy nie zamierzali tej umowy dotrzymać ${ }^{10}$, zaś w kilka dni później także ZSRR ${ }^{11}$. Rywalizacja obydwu agresorów nacechowana grabieżą i zbrodniczym sposobem prowadzenia działań wojennych, pomimo jednoznacznego określenia „sfer interesów", jest osobnym problemem - nieco drugorzędnym - w pod-

8 H. von Herwarth, Między Hitlerem a Stalinem. Wspomnienia dyplomaty i oficera niemieckiego 1931-1945, Warszawa 1992, s. 259-261, i stosowne przypisy podane przez C. Króla. Herwarthowi większość autorów przypisuje ujawnienie treści tajnego protokołu z układu o nieagresji, pracownikowi ambasady USA w Moskwie C. Bohlenowi, co oznaczało pojawienie się tej informacji na Zachodzie, ale sam Herwarth o tym milczy...

9 Agresja sowiecka, op. cit., t. I, dok. nr 41, s. 88-89.

10 B. Czarnecki, Fall Weiss. Z genezy hitlerowskiej agresji przeciw Polsce, Warszawa 1961, dok, nr 8: Dwa przemówienia Hitlera na tajnej konferencji w dniu 22 sierpnia 1939 r., s. 173-174. W II wersji przemówienia stwierdza: „Rzeczą podstawową jest przedarcie się do Wisły i Narwi". Czy Ribbentrop w tym samym czasie na Kremlu proponował to samo, czy jemu zaproponowano? Myśl - dyrektywę - Hitlera w planie operacyjnym sprecyzowano głównie w zadaniach 3 Armii gen. Georga von Küchlera, która złożona z 12 związków taktycznych i zgrupowana w południowo-wschodniej części Prus Wschodnich, głównymi siłami rozwijała się $w$ ataku na kierunek Mławy-Ciechanowa-Wyszkowa-Warszawy z zadaniem forsowania Narwi i Bugu, by nawiązać współdziałanie z wojskami 10 Armii uderzającej na Warszawę od południowego-zachodu i głębokim manewrem przez Białystok-Brześć nad Bugiem, nawiązać też łączność z wojskami Grupy Armii „Południe”. Inny fragment planowania operacyjnego i skutecznej realizacji stanowią działania 14 Armii z tej GA, która w nocy z 3 na 4 września otrzymała zadanie szybkiego dotarcia do Sanu, przekroczenia rzeki (co wykonano w Sanoku juz 9 września wieczorem) i rozwinięcia się w działaniach, które aktywnie trwały jeszcze w nocy z 18 na 19 września po wschodniej stronie Stryja. Wcześniej zajęty już był Borysław i Drohobycz. WIH MiD, T-78, r. 338, k. 6294096-097, T-312, r. 477, k. 8067021.

$11 \mathrm{Na}$ interesującym nas obszarze kwestię tę dokumentuje rozkaz bojowy n $\mathrm{r} 06$ dowódcy Frontu Białoruskiego z 25 września 1939 r., określając cele operacyjne dla poszczególnych jednostek, szczególnie 4 i 11 Armii, oraz niektórych dywizji 3 Armii, por. Agresja sowiecka, op. cit., t. III, dok. nr 60, s. 115-119. 
jętym zamierzeniu, problemem o tyle ważnym, że zaistniała konieczność określenia „linii demarkacyjnej”, która ograniczy ruch wojsk obu stron „rozgrzanych" bojem i zapobiegnie "bratobójczej” strzelaninie pomiędzy agresorami ${ }^{12}$. Ustalono, że owa linia przebiega „...wzdłuż biegu rzeki Pisa do jej ujścia do rzeki Narew; dalej wzdłuż rzeki Narew do jej ujścia do rzeki Bug; następnie rzeką Bug do jej ujścia do rzeki Wisły..." Tak powstały dalsze przesłanki do ustalenia „granicy” pomiędzy Bugiem a Niemnem.

Tymczasem w rozwoju działań wojennych większość z obu Grup Armii Wehrmachtu była na... wschód od Wisły, a pewna liczba dywizji na wschód od Bugu i Sanu. Zapadły decyzje o odwrocie ${ }^{13}$. Pomimo uzgodnień co do trybu przekazywania poszczególnych miejscowości, i w tych okolicznościach dochodziło do incydentów zbrojnych - wzajemnego ostrzeliwania się i bojów spotkaniowych. Inaczej w Przemyślu - prawobrzeżna część miasta została uroczyście przekazana 28 września o godz. 12.45 Armii Czerwonej ${ }^{14}$.

W tym samym czasie dobiegły kresu rokowania w Moskwie; Ribbentrop od wieczora 27 września negocjował szczegóły linii „granicznej”, uzyskując „enklawę Suwałek”, natomiast dalej na południe, aż do końca polskiego odcinka „granicy” u źródeł Sanu, nie zdołał wytargować ustępstw terytorialnych, ale za to dostawy paliw z kopalni Wschodniego Zagłębia Naftowego. To jednak już inna sprawa ${ }^{15}$.

Układ „o granicy i przyjaźni” podpisany został nad ranem 29 września 1939 r., ale obydwie strony odniosły go do dnia poprzedniego i pod data 28 września pozostaje w historii ${ }^{16}$. "Prawda” w nr 270 z 29 września zamieściła mapę Polski z oznaczoną „granicą" od Niemna aż do źródeł Sanu. Ale oznaczenie na mapie tej linii pomiędzy Morzami, Bałtyckim i Czarnym

12 Wobec planowanego rozwinięcia się armii niemieckich poza strefę uzgodnionych wpływów, już w nocy z 4 na 5 września pojawiła się sprawa „linii demarkacyjnej”, którą negocjowano odtąd aż do 22 września 1939 r., kiedy ogłoszono komunikat o zarysie tej linii, por. Agresja sowiecka..., op. cit., t. I, dok. 114, s. 209.

13 WIH MiD, T-311, r. 200, k. 122, 131-132, 145-147, 509-510, r. 201, k. 348-350, r. 244 , k. 307, T-312, r. 237 , k. 7781236-240. Agresja sowiecka..., op. cit., t. III, dok. nr 102, s. 279-300, przegrupowanie wojsk 4 Armii na wyznaczoną linię demarkacyjną.

14 Tamże, T-312, r. 476, k. 8066902, r. 477, k. 8067000-003, r. 478, k. 8068130. Agresja sowiecka..., op. cit., t. I, dok. nr 131, s. 237. Jest to jeden ze znakomitych raportów ppłk. Ralpha von Heygendorffa ze sztabu XVIII Korpusu GA „Południe”, oficera łącznikowego do dowódcy Frontu Ukraińskiego, który udokumentował w sposób wyjątkowo dokładny współdziałanie wojsk obydwu agresorów.

15 M. Wieliczko, Wschodnie Zagtębie Naftowe u progu wojny: wrzesień-listopad 1939 r., [w:] Studia Historyczne. Księga pamiatkowa dedykowana Czestawowi Rajcy, praca zbior. pod red. A. Wiśniewskiej, s. 279-306, Lublin 1995.

16 Agresja sowiecka..., op. cit., t. I, dok. nr 125, 126, s. 227-230. 
$\mathrm{z}$ podpisami Stalina i Ribbentropa, co jest bez precedensu $\mathrm{w}$ dyplomacji zważywszy na status obydwu sygnatariuszy..., nie mogło być podstawą do prac delimitacyjnych. Dlatego 4 października 1939 r. protokół uzupełniający w sprawie „wytyczenia granicy między ZSRR a Niemcami”, podpisany przez W. M. Mołotowa i F. Schulenburga ${ }^{17}$, umożliwiał dalsze prace. Obok ogólnego opisu przebiegu linii granicznej, łącznie z oznaczeniem na mapie rosy jskiej w skali 1:100 000, ustalono, że „linia granicy (...) będzie delimitowana w terenie przez mieszaną komisję sowiecko-niemiecką", która ustawi znaki graniczne (demarkacja), zestawi opis szczegółowy na mapie 1:25000 i rozpocznie pracę za pięć dni... Tyle ważnych informacji zawarł ten krótki „protokół uzupełniający”.

Domniemywać można, że obydwie strony posiadały przygotowane zespoły topografów wojskowych, gotowe do pracy (albo już od dawna pracujące!), bowiem 22 października 1939 r. przewodniczący delegacji niemieckiej (Hencke) oraz radzieckiej (Alexandrow) do "centralnej komisji mieszanej ZSRR i Rzeszy Niemieckiej do spraw granicy" podpisali dwie umowy ${ }^{18}$ : o wymierzeniu granicy na mapach i w terenie, oraz o oznaczeniu granicy.

W tym miejscu trzeba zwrócić uwagę na fakt bardzo znamienny: we wszystkich porozumieniach strona niemiecka używała określenia „Grenzlinie", „Interessngrenze”, „Demarkationslinie”, natomiast strona radziecka od początku powstania kwestii stref interesów obydwu państw stosowała określenie (w brzmieniu języka niemieckiego dokumentów, bo to jest bezspornie porównywalne) „der Staatsgrenze der Union der Sozialistischen Sow jetrepubliken". Dopiero specjalnym układem zawartym 17 sierpnia 1940 r. w Moskwie uzgodniono ujednolicenie nazwy ${ }^{19}$.

17 Tamże, dok. nr 142, s. 275-279.

18 AAN, Reg. Fin. 964, k.76-86. Po raz pierwszy ujawniłem fakt istnienia tych dokumentów na sesji 13-14 października 1988 r. w Uniwersytecie Mikołaja Kopernika w Toruniu, a następnie w publikacjach, Z badań nad rozmieszczeniem ludności polskiej $w$ ZSRR (listopad 1939-lipiec 1941), Migracje przez "linię demarkacyjna" w latach 1939-1940, [w:] Potozienie ludności polskiej na terytorium ZSRR i wschodnich ziemiach II Rzeczypospolitej w czasie II wojny światowej, pod red. A. Marszałka, Torun 1990, s. 91-100. W tym czasie dokumenty te były juz skopiowane i zabezpieczone $w$ innych miejscach poza AAN.

19 AAN, Reg. Fin. 964, k. 86. Ze strony niemieckiej podpisy złoży!i: Reinhold von Saucken i dr Walter Conrad, zaś radzieckiej Aleksander M. Aleksandrow i Aleksander M. Leontjew. Odtąd używano najczęściej określenia: „des Staadt-und Interessengrenze des Deutchen Reiches und der Staatsgrenze der Union Sozialistischen Sowjetrepubliken". W preambule tego układu powołano traktat z 28 września 1939 r. i protokół uzupełniający z 4 października 1939. 
Kolejną regulacją kwestii granicznych był układ, w myśl art. 26 i 27 powyższej umowy, o stosunkach prawnych przy granicy i protokół o wyznaczeniu pełnomocników obydwu stron dla odcinków granicy, podpisany 31 sierpnia 1940 r. w Berlinie. Układ wymagał ratyfikacji, co wyraźnie zaznaczono ${ }^{20}$. Ten obszerny dokument kończy proces formowania "granicy" niemiecko-radziekciej pośrodku ziem polskich.

Sa to wszystko dokumenty wagi międzynarodowej (międzypaństwowej obydwu stron - sygnatariuszy) będące przesłanką do delimitacji i demarkacji, czyli czynności technicznych w rzeczywistym ustanowieniu granicy, z wszystkimi konsekwencjami tego faktu. A były to konsekwencje wielorakie, o czym za chwilę. Wpierw kwestia delimitacji, ograniczona do fragmentu „granicy” między Bugiem a Niemnem.

W związku z przemianowaniem z dniem 3 października 1939 r. dowództwa GA „Południe" na wyższe dowództwo „Wschód” (Oberost) przejęte zostało całe dowodzenie na froncie wschodnim, czego następstwem był rozkaz nr 28 dowódcy 14 Armii „w sprawie wyjścia na linię demarkacyjną i nowych zadań na Wschodzie". Według mapy w skali 1:300 $000 \mathrm{z}$ „wyrysowaną linią demarkacyjną" poszczególni dowódcy przejęli dowodzenie na swoich odcinkach 4 października o godz. 12.00. 14 Armia od granicy węgierskiej i Przełęczy Użockiej do Dubienki nad Bugiem, dalej w dół biegu rzeki dowództwo przejmowała 3 Armia, aż do obszaru podległego dowódcy wojskowemu „Danzing-Westpreussen”, z zadaniem „...przeprowadzenia czynności okupacyjnych" 21. Warto zwrócić uwagę na synchronizację w czasie tego rozkazu z podpisaniem w Moskwie wyżej wspomnianego „protokołu dodatkowego".

Wehrmacht przejmował ochronę "granicy", co nierzadko określano w rozkazach jako „blokadę", zaś komisje delimitacyjne podjęły jednocześnie pracę na całym ciągu „granicy”; dokonywano pomiaru topograficznego, ustalano sposób oznaczenia (sytuowanie słupów granicznych zgodnie $z$ regułami demarkacji), sporządzano protokoły szczegółowe (inwentaryzacyjne) dotyczące mostów oraz wysp, kreślono przebieg „granicy” na 54 arkuszach map w skali 1:25 000 i 23 arkuszach w skali 1:5000 (z czego 22 wyrysowano ręcznie), ustalono wreszcie status pełnomocników obydwu stron (było ich 15), ich siedziby w poszczególnych odcinkach „granicy", system łączności, przekraczanie "granicy" etc. ${ }^{22}$

20 Tamże, k. 87-109.

21 WIH MiD, T-312, r. 477, k. 8066983-987.

22 AAN, Reg. Fin., 964, k. 137-187. 
Wszystko to zostało przeprowadzone do 22 października 1939 r., czyli zważywszy na długość granicy ( $1389 \mathrm{~km}$ ), jesienną porę roku i zakres prac terenowych, to demonstrowana w ten sposób „dobra wola" w likwidacji polskiej niepodległości i integralności terytorialnej może być tylko porównana $\mathrm{z}$ traktatami rozbiorowymi z końca XVIII w., bowiem ponownie Polska przestawała istnieć...

Zgodnie z "protokołem uzupełniającym" z 4 października 1939 r. pomiar "granicy" rozpoczynano ,...od punktu na rzece Igorka mieszczącego się u ujścia bezimiennego strumienia płynącego od wsi Przetok i wpadajacego do rzeki Igorka". Załącznik nr 1 obejmuje opis podziału granicy na 6 odcinków, z czego w zakres naszych zainteresowań wchodzi: Odcinek I długości $182 \mathrm{~km}, \mathrm{z}$ czego $117 \mathrm{~km}$,suchej” granicy, aż do rzeki Pisa. Stąd rozpoczynał się Odcinek II długości $140 \mathrm{~km}, \mathrm{z}$ tego $51 \mathrm{~km}$ granicy „suchej”, granicy pomiędzy Narwią i Bugiem, i dalej Odcinek III długości $432 \mathrm{~km}$ do Uściługu, w całości granicy „mokrej” z biegiem Bugu.

Załącznik nr 2 zawiera topograficzny pomiar granicy z uwzględnieniem słupów, ich numeracji, kątów ustawienia i odległości.

Załącznik nr 3 zawiera wykaz wysp, których poczynając od rzeczki Czarnej Hańczy dopływu Niemna, skąd rozpoczyna się "nasz" pomiar granicy, na tej rzece było 3 , na Wolkuszance 9 , spośród których tylko 2 przypadły stronie niemieckiej. Na Pisie było 13 wysp, z których 6 przyznano stronie radzieckiej, zaś z 12 na Narwi podobnie tej stronie przydzielono tylko 4 wyspy. Mała rzeczka Orz „przecięta” właściwie linią pomiędzy Narwią a Bugiem miała 4 wyspy i były one na terytorium niemieckim, ale zostały opisane. Łącznie do biegu Bugu było 39 wysp.

Innym nie mniej ważnym obiektem z prowadzonej demarkacji były mosty, których wykaz ujęto w załączniku $\mathrm{nr}$ 4. Na małych rzekach było wszystkiego 4 mosty, które podzielono dokładnie w połowie ${ }^{23}$. Wszystkie mosty na granicznym odcinku Narwi były zwalone i nawet nie usiłowano ich lokalizować i opisać... Natomiast na Bugu na III Odcinku, słup 16, był zniszczony most żelazny.

Szczególne znaczenie w pomiarze topograficznym (delimitacji) oraz demarkacji miało oznaczenie słupami granicznymi. Wobec tego, że na Narwi pomiędzy słupami $\mathrm{nr} 40$ a 70 , zaś na Bugu na Odcinku III od słupa nr 1 do 445 nie udało się ustawić słupów naprzeciw siebie po obu stronach „gra-

23 Tamże, Żelazny most kolejowy na linii Suwałki - Augustów długości $12,10 \mathrm{~cm}$ podzielono dokładnie dla każdej ze stron po $6,05 \mathrm{~cm}$. Był to Odcinek I, słupy graniczne 108 i 109. 
nicy", sporządzono dodatkowy protokół z dokładnym opisem tej anomalii. W grę wchodziła też zbyt duża odległość między słupami na skutek szerokości rzeki oraz pofałdowany teren nadbrzeżny.

Tak opisana i oznaczona „granica" udokumentowała zmowę agresorów i wyznaczyła szczególny rozwój stosunków okupacyjnych po obu stronach tego podziału. Badania w tym zakresie okupacji niemieckiej nie wymagaja omówienia, zaś na temat okupacji radzieckiej obszaru, który określa ciąg omawianej "granicy" od północnego wschodu po zachód, południowy-zachód, powstały już pierwsze źródłowe opracowania ${ }^{24}$. W tych okolicznościach podjać wypada nowy fragment problematyki, jako dopełnienie wyników wspomnianych badań.

Pomimo układu z 28 września 1939 r. i wysoce poprawnych stosunków pomiędzy obydwu agresorami, co dokumentuje wymiana gospodarcza (ściślej, radzieckie dostawy surowców strategicznych, w tym paliw, por. przyp. 15), obydwie strony przystąpiły do fortyfikowania "granicy przyjaźni". Wyższy dowódca SS i policji w dystrykcie lubelskim SS-Gruppenführer Odilo Globocnik już na przełomie 1939/1940 r. zaczął budowę "Ostwall" - ziemnych fortyfikacji na południu dystryktu, nad Sołokija, górnym Bugiem (granicznym) i Lubaczówką, na wschód od Sanu. Wiosną 1940 r. w rejonie Cieszanowa, Dzikowa, Bełżca i okolicy, pracowało już ponad 30 tys. Żydów.

Natomiast po stronie radzieckiej, po dokonaniu „paszportyzacji” i deportacjach, także ze strefy nadgranicznej, na obszarach kontrolowanych i strzeżonych przez wojska pograniczne NKWD, rozpoczęto gigantyczne roboty fortyfikacyjne, przenosząc ideę "Linii Stalina" na nową "granicę" ZSRR, tym razem jako „Linia Mołotowa” ${ }^{25}$. Po zbudowaniu ponad 3 tys.

24 Problem jest już wstępnie rozpoznany, że powołam się na prace M. Gnatowskiego, Białostocczyzna w granicach ZSRR (wrzesień 1939-czerwiec 1941), Potozienie ludności, op. cit., s. 141-154. Tenże, Radziecka polityka okupacyjna na Białostocczyźnie w latach 19.39-1941. Zarys tematu i problemy badawcze, [w:] Spoteczenistwo biatoruskie, litewskie $i$ polskie na ziemiach pótnocno-wschodniej II Rzeczypospolitej w latach 1939-1941, pod. red. M. Giżejewskiej i T. Strzembosza, Warszawa 1995, s. 103-119. A. Chackiewicz, Aresztowania $i$ deportacje społeczeństwa zachodnich obwodów Białorusi (19.31-1941), tamże, s. 221-136, dyskusja do s. 141.

25 J. Erickson, The Soviet Command. A Military-Political History 1918-1941, London 1962, szczególnie rozdz. XIII, s. 404-448 oraz 589-591 i stosowne przypisy. A. Cirlin i in., Inżynierijne wojska $v$ bojach za sovietskuju rodinu, Moskwa 1971, s. 41, i potem rozdz. II, 1921-1941, passim do s. 75. W latach 1931-1934 zbudowano według projektu gen. lejtn. D. Karbyszewa oraz całego zespołu współpracowników, trzynaście rejonów umocnionych, nazwanych „Linia Stalina”. Każdy rejon miał szerokość od ok. 100 do 150 km i głębokość pozycji ufortyfikowanej (w zależności od warunków terenowych) nawet do $30 \mathrm{~km}$. 
bloków bojowych różnej konstrukcji, uzbrojenia, charakteru i przeznaczenia, radziecka sztuka fortyfikacyjna nie miała sobie równych w ówczesnym świecie (mimo jakże reklamowanej „linii Maginota”, „linii Zygfryda”), i niemal natychmiast podjęto przygotowania do budowy fortyfikacji w związku z uznaniem zagrożenia $\mathrm{z}$ Zachodu.

Odcinek „granicy” pomiędzy Niemnem a Bugiem na skutek naturalnego kształtu klina „wbitego"najdalej na zachód, był obszarem już z powodu tego usytuowania wyjątkowo zagrożonym, ale „uzbrojonym” uprzednimi rosy jskimi fortyfikacjami od Modlina do Grodna (Pułtusk, Różan, Ostrołęka, Łomża, Osowiec), które w okresie międzywojennym zostały wydatnie wzmocnione ufortyfikowanym rejonem Mławy i "Rzągnowa” oraz w rejonie Wizny ${ }^{26}$. Prace budowlane koło pierwszych punktów obrony, złożonych $\mathrm{z}$ lekkich bloków przygotowanych do uzbrojenia w armaty ppanc i ckm, rozpoczęto na wiosnę 1940 r. w rejonie Grodna, a następnie coraz bardziej ku zachodowi i nad Bugiem. Łączono fortyfikacje ziemne, zalewy i podtopienia $z$ linearnymi zaporami rozbudowanych pozycji obronnych złożonych $\mathrm{z}$ różnych typów bloków oraz $\mathrm{z}$ grupami punktów oporu odległych od siebie o 3-5 km, a złożonych $z$ bloków bardziej wytrzymałych (dwukondygnacyjne, sprzężone uzbrojenia pancerno-maszynowe), które sytuowano na przewidywanych kierunkach natarcia, w terenie płaskim i otwartym, albo w „prześwitach" terenu zakrytego i zalesionego ${ }^{27}$.

Rozbudowa tych ufortyfikowanych pozycji miała wyjątkowe społeczne następstwa, bowiem ich maskowanie i w ogóle ukrycie łączyło się z wyludnieniem całych okolic, ograniczeniem dostępu do pól, łąk, lasów oraz szczególną penetracją NKWD wśród ocalałej jeszcze miejscowej ludności. Jest to wbrew pozorom ważny aspekt terroru społecznego, którego i tak nie brakło w obszarach nadgranicznych na skutek innych rozporządzeń nowej władzy.

Od Korostenia nad granicą z Polską, aż po Odessę, ta „zapora obronna” rozbudowana była nawet do 6 linii fortyfikacji ukończonych i uzbrajanych w 1937 r. Szczegółowo to rozpoznali Niemcy i opublikowali jako dokument studiów sztabowych OKH; Denkschrift über die russische Landesbefestigung, Berlin 1942, fragmenty części ogólnej s. 97-113 i szczegółowej po s. 286 dotyczą prac na zachodniej „granicy” ZSRR. Rysunki bloków, bez opisu, zostały $\mathrm{z}$ tego wydawnictwa wybrane i po przeprowadzeniu badań terenowych nad Sanem i w obszarze pomiędzy Sanem i Bugiem opisane.

26 A. Gruszecki, Twierdze rosyjskie w Polsce. Problemy ich ochrony, [w:] Lubelszczyzna. Miscellanea castellana et fortificana, 1995, numer specjalny, s. 72-75.

27 Wybrany do aneksu przykład najbardziej typowych bloków systemu fortyfikacji na „Linii Mołotowa” orientuje w przeznaczeniu taktyczno-operacyjnym tych budowli i pozycji obronnej. Obok wymienionej literatury szereg informacji wyjaśniających szczegóły podał życzliwie mgr Andrzej Małysz, któremu składam podziękowanie. 
Podjęty do bliższego rozpoznania problem „granicy" niemiecko-radzieckiej z początkowego okresu II wojny światowej na obszarze wybranym i wydatnie ograniczonym naturalnymi ciekami głównych rzek Bugu i Niemna, przyniósł $\mathrm{w}$ poczynionych spostrzeżeniach potwierdzenia i udokumentowania ogólniejszego procesu historycznego, ale w znacznie większym stopniu jego wątku regionalnego, bowiem straty i zniszczenia, nieodwracalne przekształcenia stratyfikacji społeczno-narodowościowej, są historią lokalną, bliższej (prywatnej) ojczyzny, zaś wzajemny ich związek na wybranym terytorium ujawnił niepowtarzalne i jakże doniosłe ich znaczenie. 
„Granica" niemiecko-radziecka pomiędzy Bugiem i Niemnem w latach 1939-1941

49

"Granica" niemiecko-radziecka między Bugiem a Niemnem 1939-1941

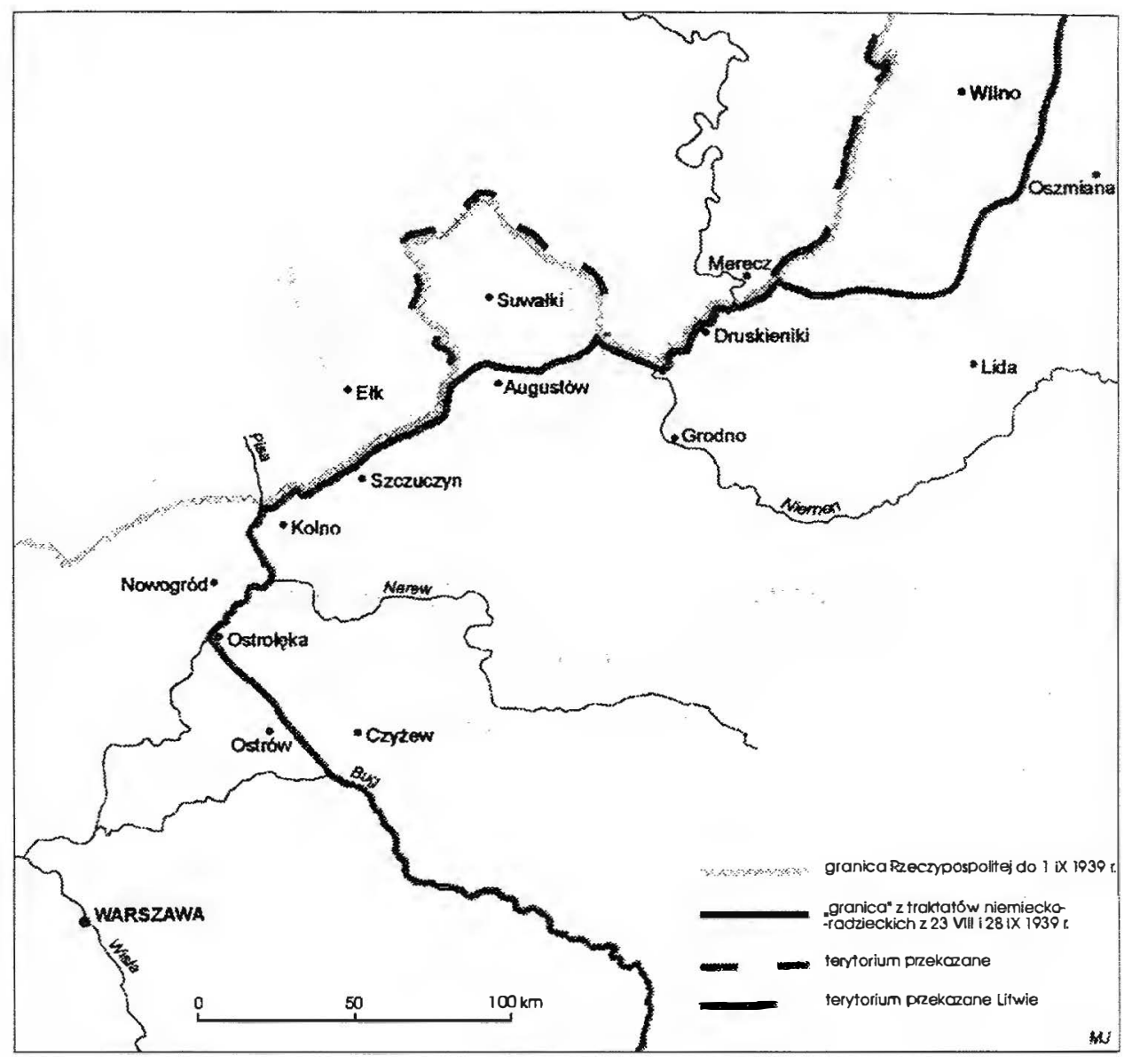


Blok obserwacyjny ewentualnie bojowy dla ckm

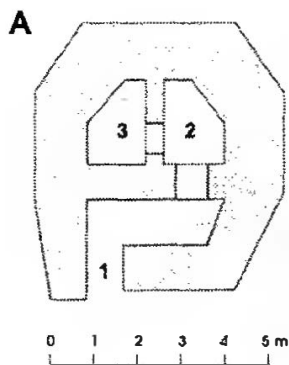

B

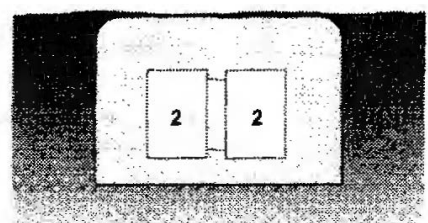

A - rzut poziomy

B - rzut poprzeczny

1 - wejście pancerne

2 - predział bojowy

3 - pomieszczenie wypoczynkowe 


\section{Blok dla armaty ppanc $76,2 \mathrm{~mm}$ lub ckm (zapasowy)}
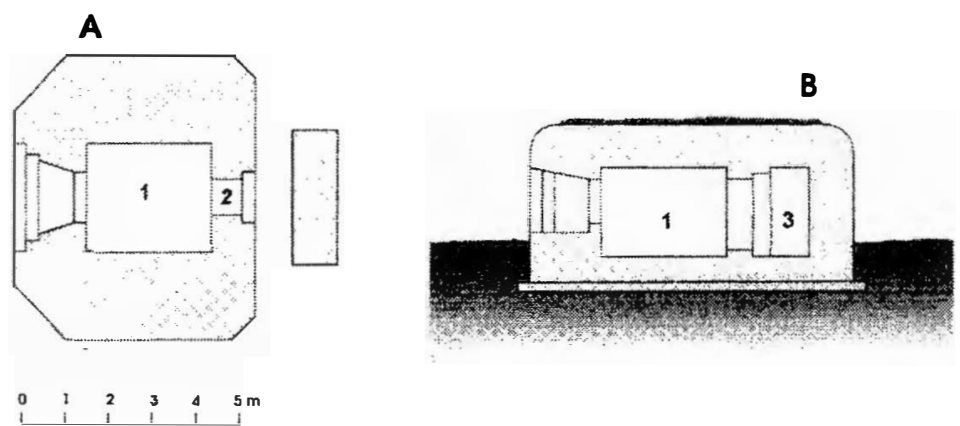

A - rzuł poziomy

B - rzut poprzeczny

1 - przedzial bojowy

2 - wejscie pancerne umocnione

3 - pomieszczenie wypoczynkowe i magazyn 


\section{Blok dla trzech ckm lub armaty ppanc i ckm}

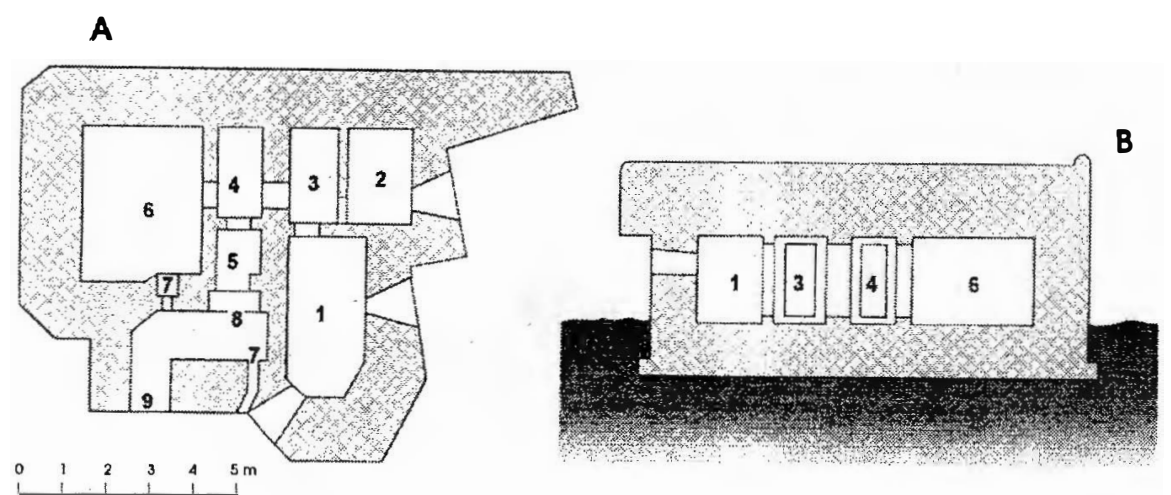

A - rzut poziomy

B - rzut poprzeczny

1 - predziad bojowy armaty ppanc i ckm

2- przedzial bojowy ckm

3 - zaplecze amunicyjne

4 - magazyny

5 - pomieszczenie sanitarne

6 - przedział wypoczynkowy

7 - komora wentylacyjna

8 - kuchnia i magazyn żywności

9 - wejście pancerne 


\section{Blok dla dwóch armat ppanc i ckm}

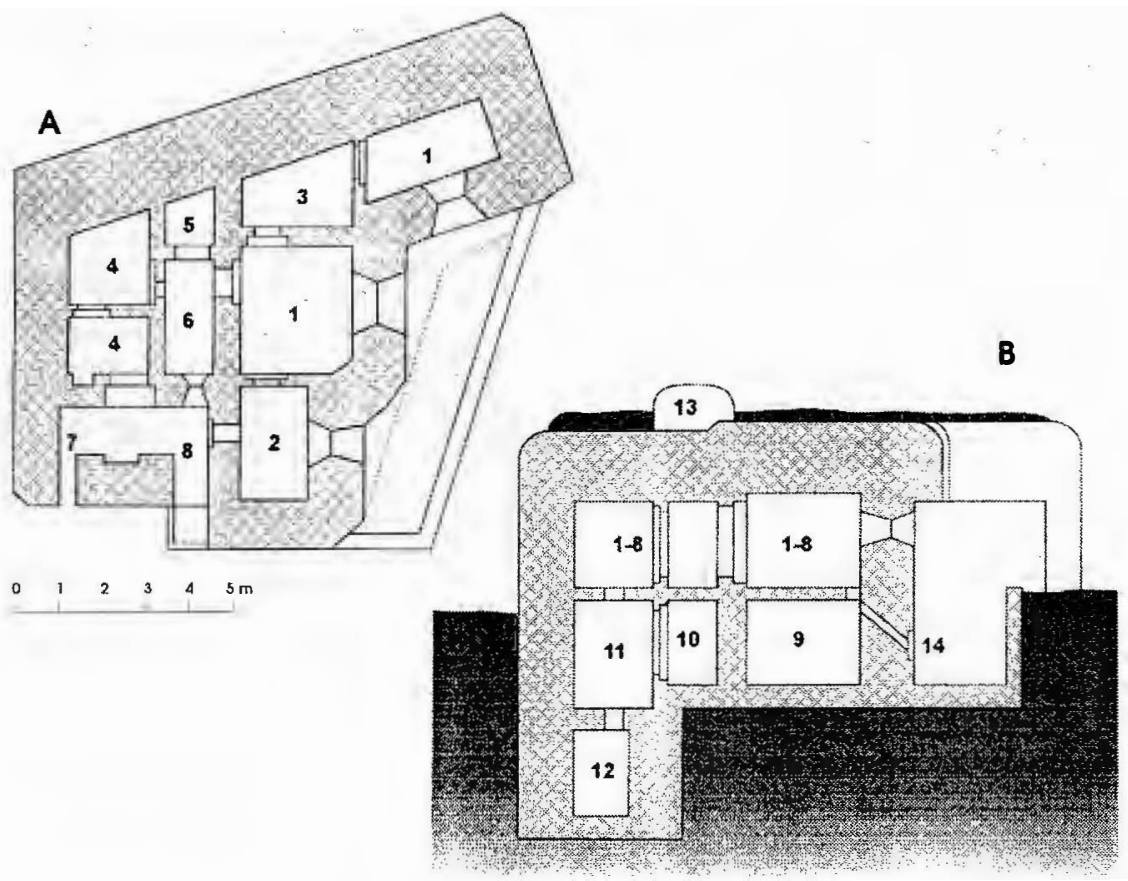

\section{A - rzut poziomy pierwszej kondygnacji}

1 - przedzialy bojowe armat ppanc $76,2 \mathrm{~mm}$

2 - przeczial bojowy ckm

3 - zaplecze amunicyjne dia armat ppanc

4 - magazyny

5 - pomieszczenie sanitarne

6 - przedziały wypoczynkowy i bojowy osłony wejścia kopuła obserwacyjna

7 - predzial wypoczynkowy z komorq wentylacyjng

8 - wejście pancerne

\section{B - rzut poprzeczny}

1-8 - pomieszczenia pierwszej kondygnacji

9 - magazyn amunicji

10 - predzialy wypoczynkowe i sanitariat

11 - przedzialy wypoczynkowe

12 - kuchnia i magazyn żywnościowy

13 - kopula pancerna

14 - wentylacja i zrut gazów bojowych 
Blok dla dwóch armat ppanc lub ckm - dwukondygnacyjny

C
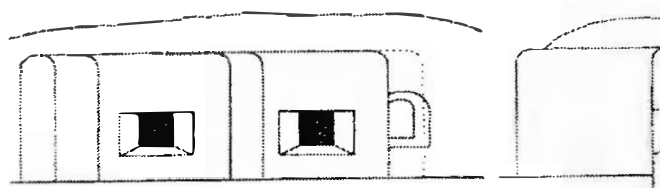

A

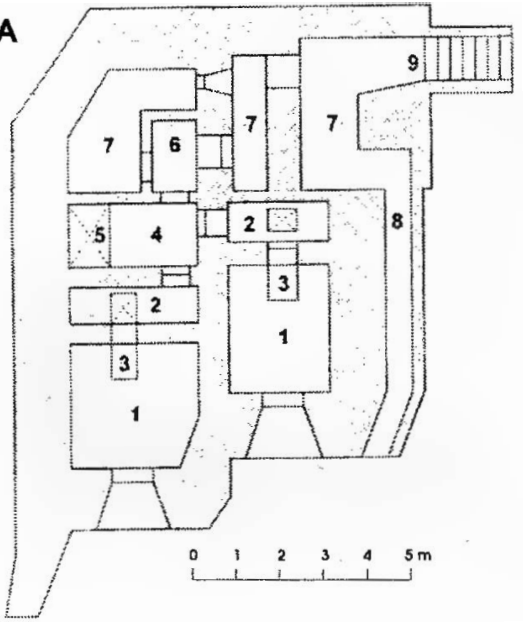

B - rzut poprzeczny

A - rzut poziomy pierwszej kondygnacji

10 - szyb transportowy

1 - przedzialy bojowe armat ppanc $76.2 \mathrm{~mm}$

11 - skład amunicji

2 - zaplecze amunicyjne dla armat ppanc

12 - ujecie wody

4 - magazyn

5 - pomieszczenie sanitarne

6 - kuchnia i magazyn żywnościowy

7 - przedzlaly wypoczynkowe

C - rzut z boku

8 - wejście zapasowe i komora wentylacyjna

9 - wejście pancerne 


\section{Blok dla dwóch ckm - dwukondygnacyjny}

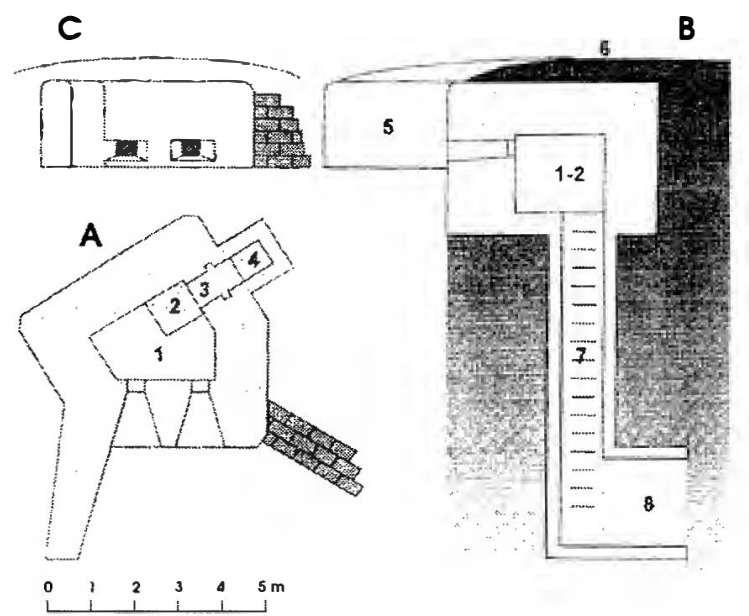

\section{A - rzut poziomy pierwszej kondygnacji B - rzut poprzeczny \\ 1 - predzial bojowy ckm \\ 2 - wentylacja i zrzut gazów bojowych \\ 3 - zaplecze amunicyjne \\ 4 - wejście zapasowe \\ 5 - mur preciwskarpowy i przedwai \\ 6 - wal ziemny \\ 7 - szyb transportowy \\ 8 - skład amunicji i prectzial wypoczynkowy}

$$
\text { C - rzut z boku }
$$

